\title{
SEASONAL VARIATION OF THE GREEN BEANS APHID, APHIS CRACCIVORA KOCH AND ITS NATURAL ENEMIES ON THE GREEN BEANS PLANTS, PHASEOLUS VULGARIS L. AT MENOUFIA GOVERNORATE
}

\author{
A.A. El-Dash, M.O. Kolaib, B.M. El-Defrawy and M. Hossiny \\ Economic Entomology \& Agricultural Zoology Dept., Fac. of Agric., \\ Menoufia University, Egypt \\ Received: Mar. 6, 2018 \\ Accepted: Apr. 18, 2018
}

\begin{abstract}
Population density of Aphis craccivora attacking green beans plants cultivated at Ashmoon, Menoufia cleared that the summer season was the highest abundance, since the total average recorded 3226.0 immature insects / 10 leaves and 340 mature insects $/ 10$ leaves, whereas in the winter season the total numbers average 81.1 immature insects /10leaves and 60.0 mature insects /10 leaves. The percentages of predators to aphid numbers reached to 34.1 and 19.75 in both seasons of study, respectively.
\end{abstract}

Key words: Population density, Aphis craccivora, Green beans, Phaseolus vulgaris L.

\section{INTRODUCTION}

The green beans Phaseolus vulgaris $\mathrm{L}$ form an important food and cash crop in different countries all over the world .In Egypt the cultivated area reach about 53000 Fadden give dry and snap bean yield about 3-5 Tons /feddan ,(FAO, 2017).the green beans is considered one of the most important source of human dietary protein and it comes in the second order as export crop after potato crop .Damage caused by the insect pests is considered the limit factor of beans production The sab suckers such as aphids cause inflict significant damage ,aphids are important pests of most cultivated crops worldwide (.Abate and Ampofo,1996 , Boivin et.al., 2012, May , Guri et al., 2011) Aphis gossypii (Glov.) populations were generally low throughout the year; the largest numbers were being recorded in November (Becquer et al., (1981). the population of Aphis craccivora were lowest on crops sown in May Metwally (1999). In Egypt observed that the population density of the cowpea aphid, Aphis craccivora had two main periods of activity, with highest counts during the third week of December and February in the first season, and during the fourth week of December and third week of March in the second season El-Defrawi et al., (2000). In India reported that red kidney bean is an important cash crop is attacked by insect pests which cause considerable damage. They included aphids, Aphis craccivora; whitefly, Bemisia tabaci. Abrol et al., (2006). The present work aimed to determine the population density of bean aphid and its natural enemies.

\section{MATERIALS AND METHODS}

This experiment was conducted at Abo Yossef, Ashmoon, Menoufiaduring a period extended from September, 2016 until December, 2016 (winter season) and from Marsh, 2017 to May, 2017.Sampls represented 50 leaves of green bean was picked up weekly in 5 paper bags, transferred into the laboratory, examined by aid of stereoscopic microscope and the different insects isolated as pest and natural enemy, counted and calculated the different ecological items. 


\section{RESULTS AND DISCUSSION}

1. Population Fluctuation of green bean aphid, Aphis craccivora:

Regarding, the population density of aphid immature stage during winter season as presented in Fig. (1) detected that the aphid density fluctuated from the low abundance in third week of October to reach the highest average of $\mathbf{3 2 0 . 0}$ insects/ 10leaves during the end of October, then the population decreased gradually, till the end of December, since the average numbers ranged between 21.0 insects /10leaves in fourth week of December and 120 insects /leaves during the first week of November.

As for, the mature stage data obtained showed few numbers occurred during mid - October and mid - November ranging between $5.0-35.0$ insects, the highest average of 35.0 insects occupied the last day of October (Table,1). The prevailing natural conditions ranged between $21-26^{\circ} \mathrm{C}$ and 68.0 percent $\mathrm{R} . \mathrm{H}$.
On the other hand, the green beans aphid during the summer season fluctuated with average numbers of $\mathbf{2 0 . 0}$ insects on February, 25 , after that the population increased gradually to reach the highest peak with average numbers of 353.0 immature insects, with beginning of fourth week of April , 2017. The population decreased to recorded 286.0 insects $/ 10$ leaves, in the second week of May (Fig. 2).

During the summer season, the population of aphid mature individuals (Fig. 2) occurred with 20.0 insects in second week of Marsh, 2017 and the population fluctuated to reach the highest average of 45.0 insects during fourth week of April and decreased gradually and averaged 25.0 mature insects /10 leaves mature insects in mid -May, 2017. The natural conditions dominated when the aphid population was in the highest numbers ranged between $28-35$ C. and 53\% R.H.

Table (1): Comparison between the number of different predators and the number of green bean aphid during two successive seasons.

\begin{tabular}{|c|c|c|c|c|c|}
\hline Month & $\begin{array}{c}\text { Aphid } \\
\text { Num. }\end{array}$ & $\begin{array}{c}\text { Predator } \\
\text { Num. }\end{array}$ & Predator (\%) & Temp ( $\left.{ }^{\circ} \mathrm{C}\right)$ & Humidity (\%) \\
\hline \multicolumn{6}{|c|}{ Winter season } \\
\hline Oct. & 59.0 & 6 & 10.2 & 25.6 & 77 \\
\hline Nov. & 35.7 & 12 & 34.1 & 24.0 & 89.3 \\
\hline Dec. & 14.5 & 4 & 27.6 & 16.3 & 79.3 \\
\hline Total & 109.2 & 22 & 22.1 & & \\
\hline & & & Summer season & & \\
\hline Mar. & 89.8 & 13 & 14.5 & 30.4 & 60.0 \\
\hline Apr. & 258.7 & 54 & 19.7 & 31.4 & 68.4 \\
\hline May & 91.1 & 16 & 17.4 & 30.5 & \\
\hline Total & 439.6 & 80 & 51.3 & & 68.0 \\
\hline
\end{tabular}




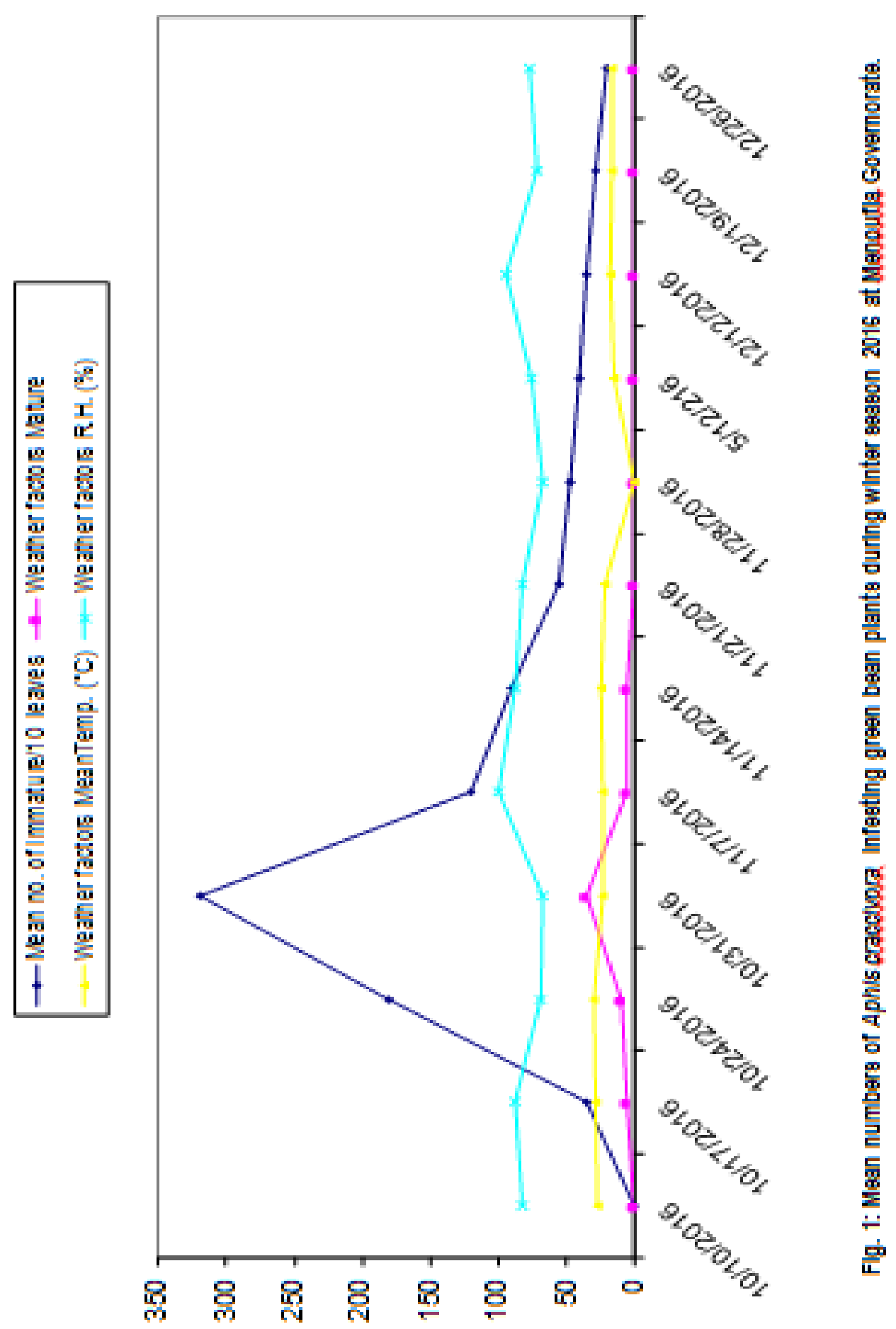




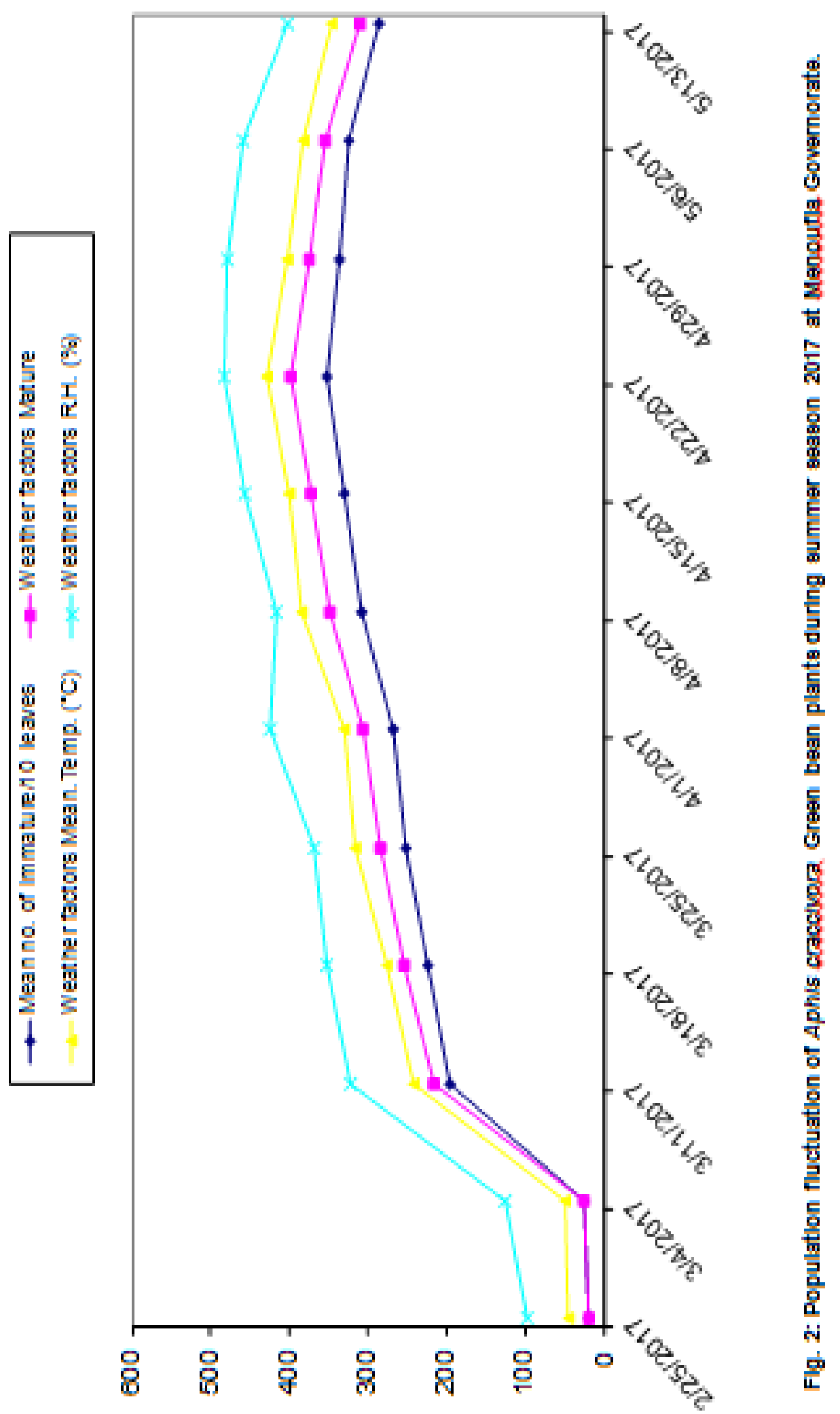


The obtained result showed that the comparing of the density in both seasons of study verify that the summer population was the higher, since the total average of the season recorded 3226 immature and $\mathbf{3 4 0}$ mature insects, while the winter season recorded total average 973 immature and 60 matures, these results meaning that the natural conditions during the summer season (28-35C. and $53 \%$ R.H.) the most suitable climate for the population built up .ElDefrawy et al. (2000) founded that the population density of $A$. craccivora had two main periods of activity, with the counts during the third week of December and February in the first season and during the fourth week of December and third week of Marsh in the second one.

The Peak of aphid population was observed in mid-May of 1996 (17.44 individuals) and in 1997 (16.20) on beans (Gaber and Sorial, 2001).

\section{Population fluctuation of predators associated with green bean aphid, $A$. craccivora:}

The obtained results in Table (1) clear that the highest average of different predators reached 12.0 individuals in November $(34.1 \%$ comparing with the total average of aphid in winter season . On the other hand, during the summer, the highest numbers of predators recorded 54.0 individuals then the population percentage recorded $19.7 \%$ during April. The natural conditions ranged between $25.5-29.0{ }^{\circ} \mathrm{C}$ and 62.5$83.5 \%$ R.H.in both seasons of study.

\section{REFERENCES}

Abate, T. and J.K.O. Ampofo (1996). Insect pests of beans in Africa: Their ecology and Management Annu. Rev. Entomol. 41: 43-73
Abrol, D.P., V.V. Ramamurthy and K. Srivastava (2006). Bean Gall Weevil and Blister Beetle as New Pests on Red Kidney Bean (Phaseolus vulgaris L.) in India. J. Asia-Pacific Entomol. 9(4): 317-320.

Becquer, A., R. Ferrandiz, A. Hernandez and R. Puga (1981). Population dynamics of aphid populations in fields of beans (Phaseolus vulgaris L.). Ciencias de la Agricultura, Cuba. No. 8: 23-28.

Boivin, G., T.S. Hance and J. Brodeur (2012). Aphid parasitoids in biological control. Canadian Journal of Plant Science. 92(1):1-12.

El-Defrawi, G. M., A. K. Emam, L.A. Marzouk and L. Rizkalla (2000). Population dynamics and seasonal distribution of Aphis craccivora and associated natural enemies in relation to virus disease incidence in faba bean fields. Egyptian J. of Agric. Res., 78(2): 627-641.

FAO (2017). The State of Food Security and Nutrition in the World 2017

Gabr, A. M. and L. S. Sourial (2001). Studies on the effect of traditional intercropping cucumber with cotton or kidney bean on aphids and whitefly abundance. Egyptian Journal of Agricultural Research. 79: 2, 431-443. 15.

May-Guri, S., I. Godonou, S. Leclercq, G. T. Yoto and B. James (2011). Assessment of aphid ecology in vegetable systems and potential for biological control agents. Acta Horticulturae. (911):227-230.

Metwally, S. A. G. (1999). Effect of planting date and certain weather factors on the population fluctuations of three insect pests infesting kidney beans in Qualyobia governorate. Egyptian Journal of Agricultural Research. 1999. 77: 1, 139-149. 
دراسة التذبذب العددى لحشرة المن التى تصيب نباتات الفاصوليا والأعداء الحيوية المرتبطة بها تحت الظروف الحقلية فى محافظة المنوفية

أحمد احمد الاش ، محمد على عمر كليب ، باسم محمد الدفراوى ، محمد حسينى محمد

$$
\text { يوسف }
$$

قسم الحشرات الاقتصادية والحيوان الزراعى - كلية الزراعة - جامعة المنوفية - مصر

الملخص العربى ت تصني

تعتبر الفاصوليا من أهم محاصيل الخضر الاقتصادية فى مصر والعالم والتى تصاب بالعديد من الافات التى تسـبب

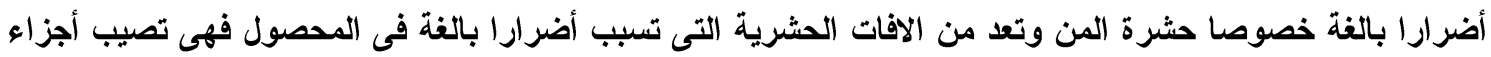

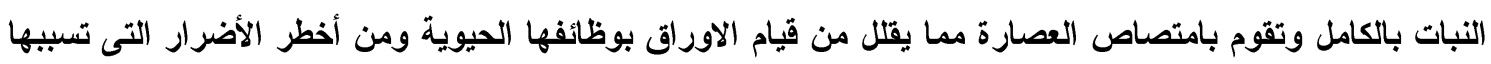

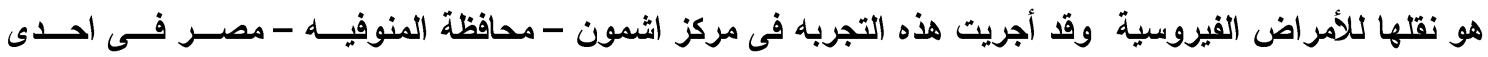

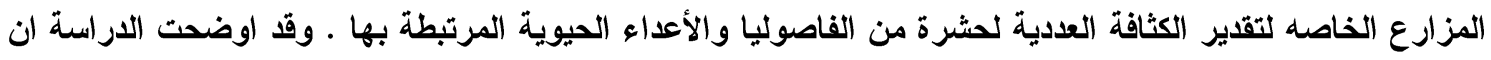

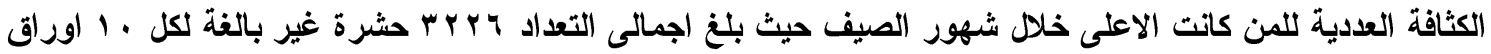

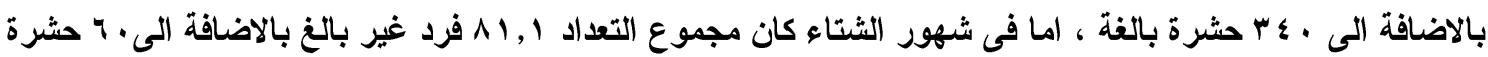

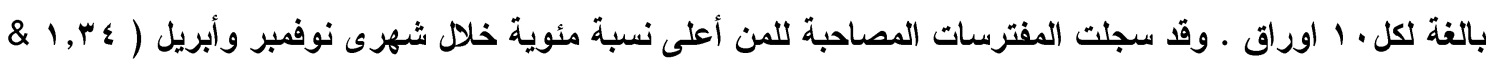

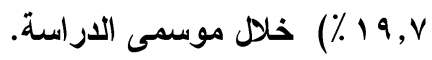


Seasonal variation of the green beans aphid, aphis craccivora koch .................

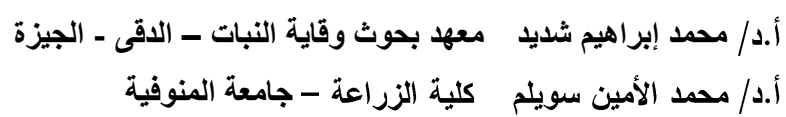


Menoufia J. Plant Prot., Vol. 3 June (2018): 93 - 98 